\title{
Effect of salt grain additions on fibrous peat consolidation
}

1 Lin Zhang BEng

Postgraduate Research Student, Department of Civil, Structural and Environmental Engineering, Trinity College Dublin, Ireland
2 Brendan C. O'Kelly PhD, FTCD, CEng, CEnv, MICE Associate Professor, Department of Civil, Structural and Environmental Engineering, Trinity College Dublin, Ireland
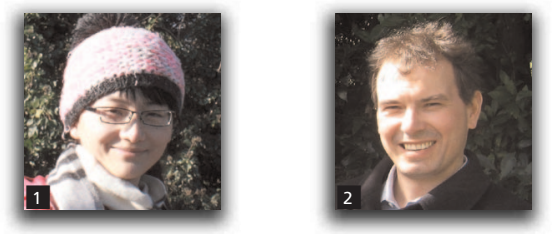

Peat has been considered a problematic geotechnical material, with extremely high water content, low shear strength and high compressibility. Although initially high, fibrous peat undergoes dramatic reductions in permeability under compression, with secondary compression (creep) accounting for a large proportion of the settlement under loading. The key to accelerating the whole consolidation process for fibrous/hemic peats is to create a means of accelerating water flow from micropores (within the cellular structure) or humus contained in the peat. This paper presents the results of preliminary laboratory trials performed using the hydraulic consolidation (Rowe) cell apparatus to investigate a novel approach involving the addition of salt grains to fibrous peat towards accelerating its rate of primary consolidation and reducing its creep rate. Under similar loading conditions, salt-treated specimens were found to have reduced rate and magnitude of creep settlement, explained by larger volumes of micropore water expelled during primary consolidation.

\section{Notation}

$C_{\alpha} \quad$ coefficient of secondary compression

$C_{\mathrm{sec}} \quad$ secondary compression ratio

$c \quad$ salt concentration

$c_{\mathrm{V}} \quad$ coefficient of primary consolidation

e void ratio

$e_{0} \quad$ initial void ratio

$m_{\mathrm{p}} \quad$ wet mass of peat

$m_{\mathrm{s}} \quad$ mass of salt grains

$m_{\mathrm{V}}$ EOP volume compressibility coefficient based on 'end of primary' consolidation settlement

$\rho_{\mathrm{w}} \quad$ density of pore water

$t \quad$ time

$u \quad$ untreated peat specimen

w water content

\section{Introduction}

Peat is considered a problematic geotechnical material, with extremely high water content, low shear strength and high compressibility; secondary compression (creep) accounting for a large proportion of the settlement under loading (Farrell, 2012; Mesri and Ajlouni, 2007; O'Kelly, 2009). Primary consolidation of fibrous peat occurs rapidly on account of its high initial permeability (typically 1000 times that of soft clay/silt deposits), although it undergoes dramatic reductions in permeability under compression (Mesri and Ajlouni, 2007). For instance, in the case of fibrous peat, the ratio of permeability change index (i.e. change in void ratio to change in logarithm of vertical permeability) to in situ void ratio is typically about $0 \cdot 25$, compared to approximately $0 \cdot 50$ for soft clay/silt deposits (Mesri and Ajlouni, 2007).

Preloading/surcharging in combination with vertical drains is the most widely applied technique used to improve the geomechanical properties of peat and other organic soil deposits (Mesri and Ajlouni, 2007; Mesri et al., 1997; Santagata et al., 2008). However, several investigators (Lake, 1961, 1963; McNulty, 1991; Mesri and Ajlouni, 2007) have suggested that vertical (sand) drains have little effect in accelerating the settlement rate for fibrous peat, considering the peat's high initial permeability and dominant creep effects. Chemical treatments using cement, lime, fly ash or other additives have also been used in practice to improve the geomechanical properties of peat (Deboucha et al., 2008; Hebib and Farrell, 2003; Hughes and Glendinning, 2004; Kalantari et al., 2011; Kazemian et al., 2012; Wong et al., 2008), although the large volumes of additive required often make such techniques prohibitively expensive. As an alternative, researchers (Osorio, 2012; Osorio et al., 2008, 2010) at Trinity College Dublin (TCD) have been investigating the vacuum consolidation technique for accelerating the consolidation of fibrous peat. However, physical/chemical blockage of the vacuum lines, along with difficulties in transporting and setting up the vacuum 
equipment at soft peat deposits, has tended to handicap its field application. Another novel approach proposed by the TCD research group involves increasing the degree of humification (decomposition) of fibrous peat in order to reduce creep settlements (Pichan and O'Kelly, 2012, 2013), although destroying the peat material's essentially fibrous structure also has the effect of reducing its coefficient of permeability (Hobbs, 1986; O'Kelly, 2005a, 2006).

One of the most striking properties of peat is its extremely high water content, often in the range of $1000-2000 \%$ by dry mass (Hobbs, 1986). Pore water in the open interstices of the peat material is ready to drain under load application. However, a large quantity of water continues to be gradually released over a long period of time on account of peat's large water-holding capacity, provided by both micropores and humified organic content (ASTM, 2004; Hobbs, 1986). For fibrous peats, researchers (Adams, 1965; Berry and Poskitt, 1972; Dhowian and Edil, 1980; O'Kelly, 2013; Wong et al., 2009) have postulated a twolevel structure of micro- and macropores. In this context, micropores are provided by the cellular structure within fibrous peat particles. Macropores are formed by the interstitial space between interwoven solid particles. Between one- and two-thirds of the water content of fibrous peat is contained within micropores (Landva and Pheeney, 1980; Ohira, 1977). Primary consolidation mainly involves drainage of macropore water that is ready to drain. The creep portion of fibrous peat settlement is explained by the slow process of drainage from micropores to macropores, which manifests as dramatic reductions in permeability of the material under loading. It is commonly advocated that for fibrous peat, creep occurs simultaneously with the process of primary consolidation (den Haan, 1996; den Haan and Edil, 1994; Edil et al., 1991). In this context, primary consolidation is explained mainly as the hydrodynamic process whereby macropore water drains, along with micropore water flowing into macropores at a slow rate, with creep merely consisting of the later process. In peats having a higher degree of humification, porous structures have been degraded somewhat, although a similar analogue can be invoked, namely gradual release of water occurs from decayed plant humus, a material that also has high water-holding capacity. Landva and Pheeney (1980) investigated the microscopic properties of fibrous peat and observed that there was little visual difference in fabric between that of natural material and the same material compressed under an applied stress of $7 \mathrm{MPa}$. It is widely accepted that a major consideration regarding the decrease in coefficient of permeability of peat is its large water-holding capacity (Hemond and Goldman, 1985). Hence, the key to accelerating the whole consolidation process for fibrous/hemic peats is to create a means of accelerating water flow from micropores or humus contained within the peat structure.

This paper sets out to investigate the effects of the addition of salt (sodium chloride, $\mathrm{NaCl}$ ) grains on the compression/consolidation response of fibrous peat under loading towards developing a novel method of ground improvement. Preliminary laboratory trials have been performed in order to investigate changes in the rates of primary consolidation and creep achieved for salt-treated fibrous peat specimens.

\section{Methodology}

Based upon the two-level structure and consolidation mechanism described earlier in the paper, the creep portion of the settlement response for slightly decomposed fibrous peat material is largely caused by the secular process of micropore water movement to macropores (de Josselin de Jong, 1968). For humic peat, creep is the manifestation of the gradual release of water molecules from humus. Chen et al. (1976) indicated that the sponge-like structure of humus has water and other liquids chemically (or otherwise firmly) bound within microstructures. The process of ionisation of salt grains induces the movement of nearby pore water towards them. Dissolving salt grains also release a high-ion-concentration water layer around them, producing electrostatic potential and concentration potential fields that can attract counter-ions in the micropore water, thereby inducing further movement of fluid with ions. Based on this concept, a new approach is proposed towards accelerating the rate of consolidation and reducing the creep rate for fibrous peat. This involves adding salt grains to the peat during its creep stage (i.e. proportion of macropore water remaining within the peat material is small). Sodium and chloride ions are released around the surface of the salt grains by the ionisation process (Figure 1). As micropore water can transfer to macropores quicker, pore water ready to drain under loading gathers around salt grains during the ionisation process, accelerating drainage from micropores to macropores, thereby accelerating the whole consolidation process for the peat material. For the purpose of this investigation, sodium chloride salt was selected to accelerate consolidation since sodium chloride solution has neutral $\mathrm{pH}$. Increases in $\mathrm{pH}$ value of the pore water in peat are likely to cause an increase in the rate of decomposition of constituent organic matter (Pichan and O'Kelly, 2012, 2013).

As the peat material tested in the present study was moderately decomposed, fine, fibrous peat, macropore interstices are very

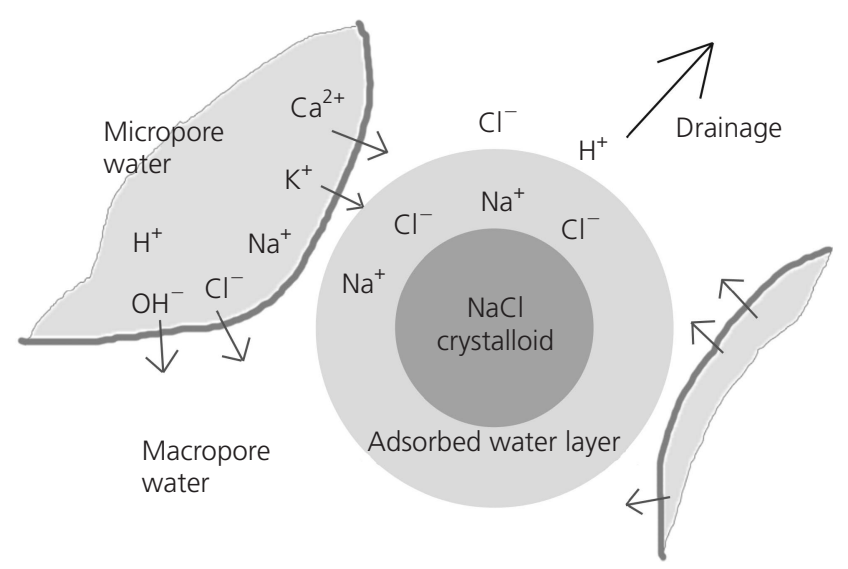

Figure 1. Sodium chloride grain dissolving in peat macropores 
small and contain colloidal matter that can be undecomposed organic constituents of the original plant material, such as ligin, or organic colloids (humus) produced by complete/partial decay of plant material through bacterial processes (Pichan and O'Kelly, 2013). Two hypotheses (Stevenson, 1994) are usually considered in describing the colloidal portion in soils and these are presented below.

In the first hypothesis, which is more applicable for inorganic soils, colloidal substances are assumed to consist of rigid spherical particles, in aqueous solution, include an electric double layer and a mantle of hydration water. For the double layer, the inner layer is immediately adjacent and fixed to the surface of the colloidal particle. The outer layer, of opposite sign, is movable and extends into the supporting medium. For instance, Figure 2 shows the expansion of the diffuse hydration layer for nano-scale silica induced by the presence of sodium ions in pure water (Song et al., 2005) since the hydrated sodium ions are larger in size compared with the water molecules. In the present investigation, the peat test materials considered have low $\mathrm{pH}$ values. Hence monovalent $\mathrm{H}^{+}$is attracted to the hydration double layer located around the negatively charged colloids. In the presence of sodium cations, the exchange of hydrated $\mathrm{Na}^{+}$ions with $\mathrm{H}^{+}$occurs, with the extent and rate of this reaction dependent on the cationexchange capacity of the organic colloid molecules. It should be noted that the cation-exchange capacity of soil organic matter decreases markedly with decreasing $\mathrm{pH}$ value (Helling et al., 1964) on account of the decreased ionisation of the acidic groups (mostly $\mathrm{COOH}$ ) at lower $\mathrm{pH}$. For ions of equal valency, the least hydrated have the highest adsorption energy (Stevenson, 1994). Hence in acidic solutions, $\mathrm{H}^{+}$is more stably adsorbed to the colloid particle than hydrated sodium ions. The diffuse hydration layer forms on account of electrostatic attraction, since humic particles have negative charge. According to Coulomb's law, the adsorption force is inversely proportional to the square of the distance between the ions and colloid particle. The adsorption force between ions and the colloid particle decrease with the exchange of hydrated sodium ions with water molecules $\left(\mathrm{H}_{3} \mathrm{O}^{+}\right)$. Hence water molecules adsorbed in the diffuse hydration layer are easier to drain under loading.

In the second hypothesis, humic colloids (long-chain molecules with two/three-dimensional cross-linked macromolecules) can adopt the configuration of a flexible coil in solution. Since these colloid molecules/polymers have natural negative charge, cations such as $\mathrm{H}^{+}$in solution are attracted around colloids. Ong and Bisque (1968) postulated that in the presence of electrolyte, the humus macromolecule changes from a hydrophilic to hydrophobic type colloid. It was believed that in aqueous solution, the polymers assumed a stretched configuration on account of mutual repulsion of negatively charged functional groups. When electrolyte was added, cations are attracted to negative groups, thereby causing a reduction in intermolecular Coulombic repulsion in the polymer chain. This in turn favours coiling of the chain, causing a reduction in the amount of hydration water held by the colloid.

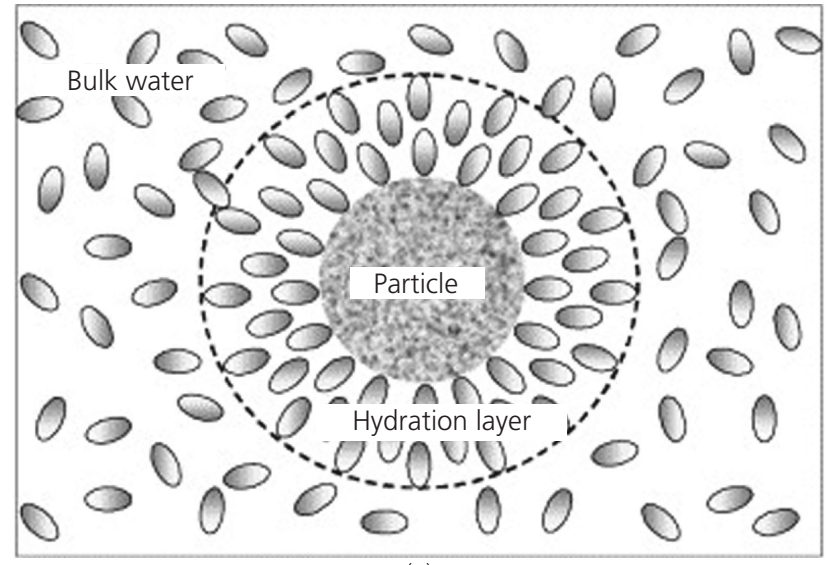

(a)

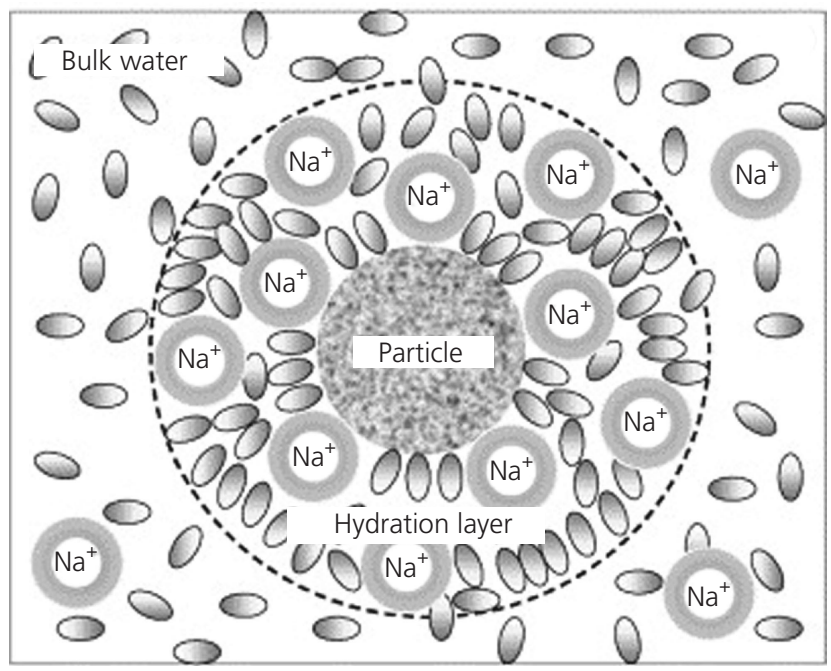

(b)

Water, molecular

Hydrated ion

Figure 2. Illustration showing expansion of diffuse hydration layer of nano-scale silica induced by sodium ions in pure water (Song et al., 2005)

Taking a negatively charged organic molecule as $\mathrm{R}(\mathrm{COO}) \mathrm{H}$, the presence of sodium ions also causes a shift in cation attraction to occur in the diffuse hydration layer (Equation 1) and hence more 'free' water can be released.

$$
\mathrm{R}(\mathrm{COO}) \mathrm{H} \mathrm{H}^{+}+\mathrm{H}_{2} \mathrm{O}(\mathrm{OH})^{-}+\mathrm{Na}^{+}
$$

$$
\text { 1. } \rightarrow \mathrm{R}(\mathrm{COO}) \mathrm{HNa}^{+}+\mathrm{H}_{2} \mathrm{O}
$$

In summary, the two hypotheses presented above lead to the same conclusion that the presence of sodium ions assists in the release of more free water molecules from the peat structure. The active period of the salt treatment is the period over which salt grains remain undisolved; that is, the effect on the consolidation rate is 
marginal once the salt has been fully dissolved. Hence fine salt is expected to have a shorter active duration period compared with coarse salt, leading to the conclusion that an appropriate grading of salt should be chosen when considering an acceleration of the consolidation rate for fibrous peat.

\section{Test materials}

In the present study, experimental laboratory trials were performed on two saturated peat materials to investigate the repeatability of the proposed treatment method, also considering scale (test specimen and salt grain size) effects. Saturated peat material was obtained from a depth of $2.5 \mathrm{~m}$ below the ground surface at Clara raised bog, County Offaly, Ireland. Some of this material was subsequently allowed to decompose further, from $\mathrm{H} 4$ to $\mathrm{H} 6$ on the scale of von Post (Landva and Pheeney, 1980), in the laboratory environment. These test materials will be referred to as $\mathrm{P} 1$ and $\mathrm{P} 2$ respectively, with selected properties listed in Table 1. Both peat materials were categorised as hemic or moderately decomposed peat (fibre content, FC $<67 \%$; ASTM, 2007) and classified as SCN-B3-F3(S)-R1(N)-W1(N) on the extended von Post scale (Landva and Pheeney, 1980). Further details on the geomechanical behaviour and properties of the Clara peat under study have been reported by O'Kelly and Zhang (2013) and Zhang and O'Kelly (2013).

The chemistry of the groundwater at Clara raised bog has been reported by Kelly (1993) as follows: calcium (Ca), $140 \mathrm{mg} / \mathrm{l}$; magnesium $(\mathrm{Mg}), 8.3 \mathrm{mg} / \mathrm{l}$; potassium $(\mathrm{K}), 1.1 \mathrm{mg} / \mathrm{l}$; sodium (Na), $9.7 \mathrm{mg} / \mathrm{l}$; chloride $(\mathrm{Cl}), 20.0 \mathrm{mg} / \mathrm{l}$. The solubility of sodium chloride in pure water is $350 \mathrm{~g} / 1$ at a temperature of $25^{\circ} \mathrm{C}$. In the present study, a low concentration of $30 \mathrm{~g}$ dry salt/ 1 pore water (from Equation 2, taking the density of pore-water $\rho_{\mathrm{w}}$ as $1 \mathrm{~g} / \mathrm{ml}$ ) was adopted for the trials since, at higher concentrations, electrochemical reactions occurring between the salt solution and experimental apparatus may cause noticeable pitting of steel material in the latter. Two gradings of salt were also considered (Figure 3) in order to investigate possible effects of salt grain size on the peat consolidation rate.

2. $\quad c=\frac{m_{\mathrm{s}}}{\left\{m_{\mathrm{p}}[w /(100+w)]\right\} / \rho_{\mathrm{w}}}$

\begin{tabular}{lcc}
\hline Material type & P1 & P2 \\
\hline Water content: \% & 1014 & 1081 \\
Specific gravity of solids & 1.42 & 1.50 \\
Degree of humification & $\mathrm{H} 4$ & $\mathrm{H} 6$ \\
Loss in dry mass on ignition: \% & 98.6 & 94.9 \\
Fibre content: \% & 63.5 & 50.9 \\
pH value & 3.8 & 4.5
\end{tabular}

Table 1. Selected properties of peat test materials

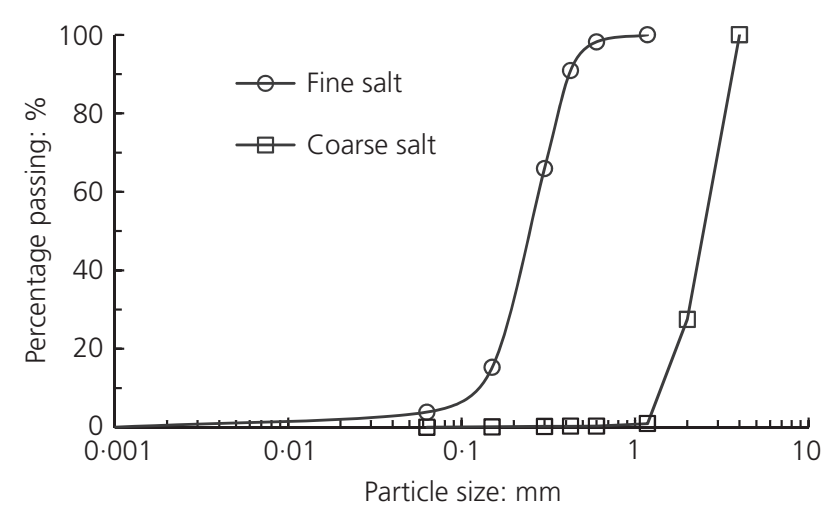

Figure 3. Grading of salts considered

where $c$ (in $\mathrm{g} / \mathrm{l}$ pore water) is the salt concentration; $m_{\mathrm{s}}$ is the mass of salt grains; $m_{\mathrm{p}}$ and $w$ are the initial wet mass and water content (as \%), respectively, for the peat material.

\section{Materials and specimen preparation}

Reconstituted specimens of peat test materials P1 and P2 were first consolidated using a $254 \mathrm{~mm}$ diameter hydraulic consolidation (Rowe) cell (BSI, 1990), set up for one-way specimen drainage by way of the specimen top surface to atmosphere (O'Kelly, 2005b). These consolidation tests were performed in order to reduce, somewhat, the macropore water that was ready to drain from the test materials. Compared with initial water contents of $1014 \%$ and $1081 \%$, the consolidated specimens P1 and $\mathrm{P} 2$ had water contents of $602 \%$ and $640 \%$ respectively.

\section{Test programme}

After test specimens of P1 and P2 peat materials had been consolidated for cumulative periods of 105 and 17 days, respectively (see Table 2 for further details), additional testing was performed on material from the compressed peat cakes using both 254 and $76 \mathrm{~mm}$ diameter hydraulic consolidation cells. In preparation, the peat cake of P1 material was removed from the consolidation cell, crumbled and thoroughly hand-mixed with addition of the fine salt at a concentration of $30 \mathrm{~g} / 1$ pore water before being compacted back to the same specimen height in the $254 \mathrm{~mm}$ diameter consolidation cell. By compacting the test specimens back to the same height achieved at the end of compression loading of the peat cakes, air voids could be excluded as much as possible, thereby maintaining near full saturation, confirmed by measured pore pressure coefficient $B$ values of greater than 0.95 at the start of these tests.

In the case of peat material P2, two $76 \mathrm{~mm}$ diameter test specimens were prepared in a similar manner from the peat cake; one specimen had been treated with coarse salt, again at $30 \mathrm{~g} / 1$ concentration, the other had no treatment. Shorter duration consolidation periods were adopted for salt-treated specimens (see Table 2) in order to reduce exposure of the consolidation cell and instrumentation to possible chemical damage. The settlement and pore water pressure responses and final efflux volume of the test 


\begin{tabular}{lccccc}
\hline Peat material & \multicolumn{3}{c}{ P1 } & \multicolumn{2}{c}{ P2 } \\
\hline Cell diameter: mm & 254 & 254 & 254 & 76 & 76 \\
Stage applied stress: kPa & 20 & 40 & 20 & 20 & 40 \\
Material preparation stage: & & & & & \\
Initial height: mm & $99 \cdot 1$ & $83 \cdot 7$ & $92 \cdot 0$ & - & - \\
Stage duration: days & 14 & 91 & 7 & - & - \\
Main test: Initial height: mm/stage duration: days & & & \\
- untreated & - & - & - & $24 \cdot 65 / 1$ & $22 \cdot 35 / 17$ \\
- treated with fine salt & - & $58 \cdot 8 / 1$ & - & - & - \\
- treated with coarse salt & - & - & - & $19 \cdot 05 / 1$ & $16 \cdot 53 / 8$
\end{tabular}

Table 2. Summary of consolidation test programme

specimens were measured. Although the concentration of $\mathrm{Na}^{+}$ ions was not directly measured, salt concentrations were determined using two approaches. Salt was extracted from solution by oven-drying the pore water expelled from the salt-treated specimens. Salt was also extracted from the test specimens after termination of the consolidation tests. In this case, the test specimens were oven-dried, ground using a pestle and mortar to pass the $425 \mu \mathrm{m}$ sieve, soaked in distilled water for a $48 \mathrm{~h}$ period after which the suspension was filtered using Whatman number 4 filter paper. The salt was then extracted by oven-drying the filtrate.

\section{Test results and analyses}

Figure 4 shows axial strain and excess pore water pressure ratio $U$ (i.e. ratio of measured excess pore pressure to stress increment)
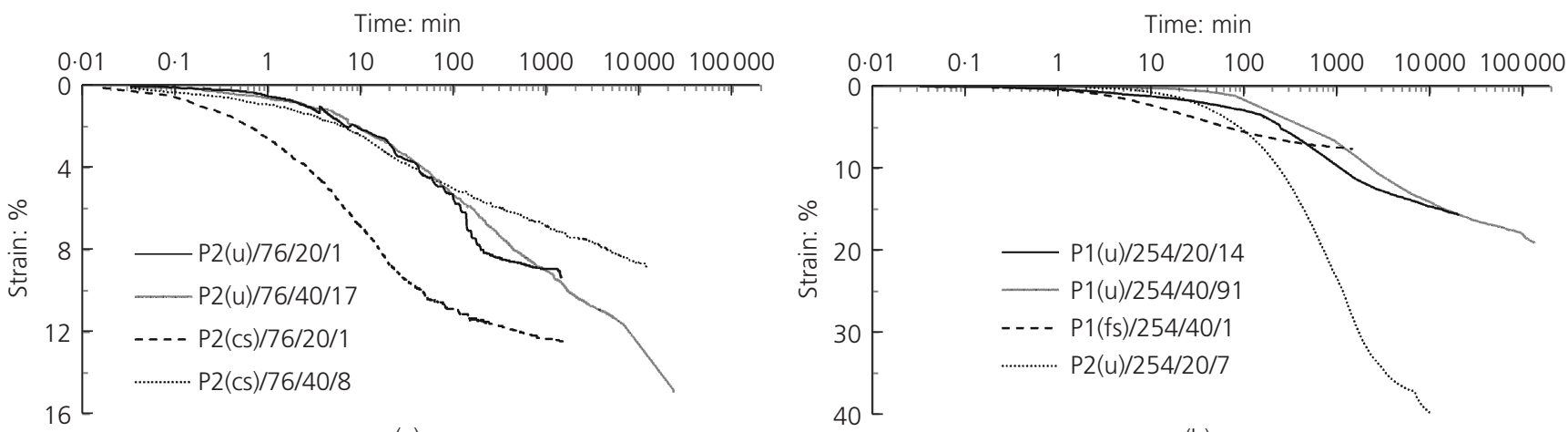

(a)

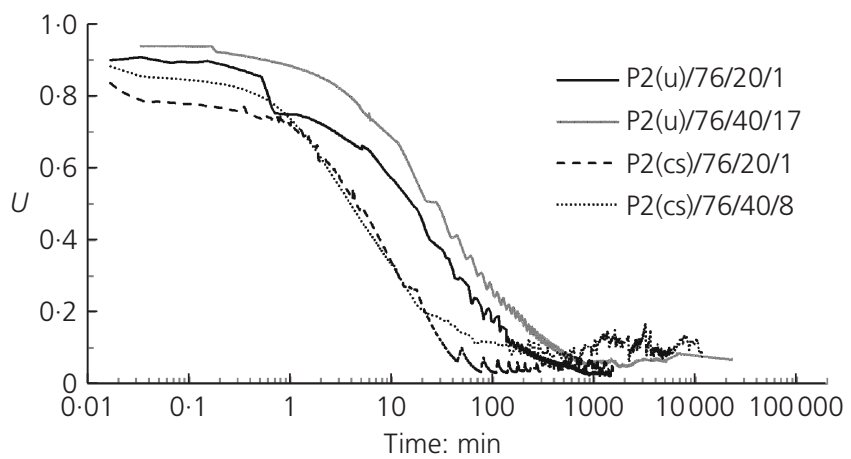

(c)

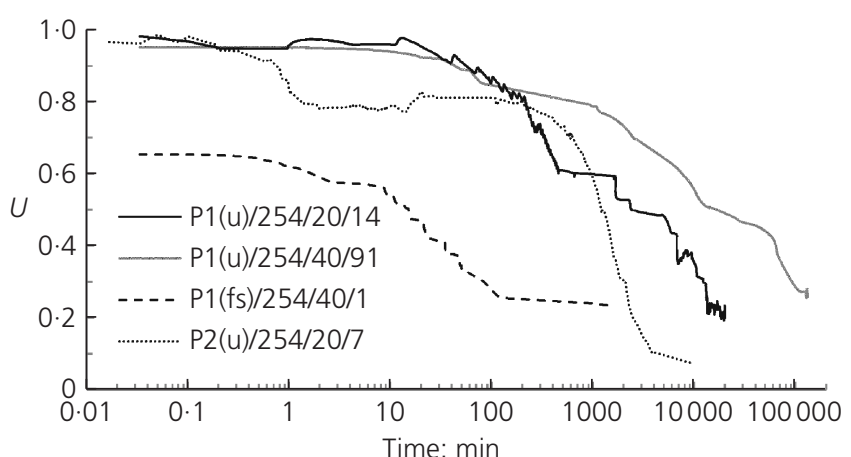

(d)

Figure 4. Axial strain and pore pressure responses against elapsed time: (a) axial strain for $76 \mathrm{~mm}$ diameter specimens; (b) axial strain for $254 \mathrm{~mm}$ diameter specimens; (c) pore pressure ratio, $U$, for $76 \mathrm{~mm}$ diameter specimens; (d) pore pressure ratio, $U$, for $254 \mathrm{~mm}$ diameter specimens 
responses determine from the settlement and excess pore water pressure data. Note that the specimens have been labelled as follows: test material (cs, coarse salt; fs, fine salt; u, untreated)/ cell diameter $(\mathrm{mm}) /$ loading stage $(\mathrm{kPa}) /$ test duration (days); for example, P1(fs)/254/40/1 indicates peat material P1 treated with fine salt, consolidated in the $254 \mathrm{~mm}$ diameter cell under an applied stress of $40 \mathrm{kPa}$ over a period of 1 day.

The data curves for the $76 \mathrm{~mm}$ diameter cell in Figures 4(a) and 4(c)) show that under the same applied stress and loading period, salt-treated specimen P2(cs)/76/20/1 experienced greater strain compared with untreated peat specimen P2(u)/76/20/1. Dissipation of excess pore water pressure also occurred quicker for the salt-treated specimen for both the 20 and $40 \mathrm{kPa}$ load stages (Figure 4(c)). The same trend was evident in the data curves for the $254 \mathrm{~mm}$ cell (Figures 4(b) and 4(d)).

The difference in shape of the strain curves for peat materials $\mathrm{P} 1(\mathrm{u}) / 254 / 20 / 14$ and $\mathrm{P} 2(\mathrm{u}) / 254 / 20 / 7$ in Figure $4(\mathrm{~b})$ can be attributed to fibre effects, with the P2 material of von Post H6 experiencing greater strain than the P1 material of von Post $\mathrm{H} 4$ ( $\mathrm{FC}=50.9 \%$ and $63.5 \%$ respectively). Among the $254 \mathrm{~mm}$ diameter consolidation tests on P1 material, the P1(fs)/254/40/1 curve defined the lowest strain boundary, which was to be expected since the test material had already been consolidated (and also allowed to age somewhat) over the 91 day loading period under $\sigma_{\mathrm{v}}=40 \mathrm{kPa}$ during the material preparation stage. After a relatively short period, the P1(fs)/254/40/1 curve was quickly into secondary compression. This is consistent with the reduced initial value and quicker rate of dissipation of excess pore water pressure (Figure 4(d)) for which the salt effect was also a determinative factor.

Quantitatively, the respective coefficient of primary consolidation, $c_{\mathrm{V}}$, values calculated by Taylor's method (Taylor, 1942) for salttreated specimens P2(cs)/76/20/1 and P2(cs)/76/40/8 of 11.5 and $2.2 \mathrm{~m}^{2} /$ year are greater than the values of 9.9 and $1.5 \mathrm{~m}^{2} /$ year determined for untreated peat specimens P2(u)/76/20/1 and $\mathrm{P} 2(\mathrm{u}) / 76 / 40 / 17$, respectively, which confirms a higher consolidation rate for salt treatment. The value of the coefficient of volume compressibility associated with the primary consolidation stage,

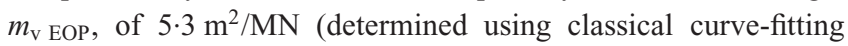
techniques) was also larger for salt-treated specimen P2(cs)/76/ 20/1 compared with untreated peat specimen P2(u)/76/20/1 $\left(4 \cdot 1 \mathrm{~m}^{2} / \mathrm{MN}\right)$. Similarly, calculated values of the coefficient of permeability, $k_{\mathrm{v}}$, were marginally greater for salt-treated material; for example, $1.9 \times 10^{-8}$ and $1.3 \times 10^{-8} \mathrm{~m} / \mathrm{s}$ for specimens $\mathrm{P} 2$ (cs)/76/20/1 and P2(u)/76/20/1, respectively. However, under the second load stage at $40 \mathrm{kPa}$, peat specimen $\mathrm{P} 2(\mathrm{u}) / 76 / 40 / 8$ experienced a similar rate of consolidation but greater creep rate than salt-treated specimen P2(cs)/76/40/1 (see Figure 4(a)), with corresponding $m_{\mathrm{vEOP}}$ values of 4.3 and $3.0 \mathrm{~m}^{2} / \mathrm{MN}$. Two reasons are proposed to explain this apparent anomaly. First, the salt treatment had produced larger strain under the load stage at $20 \mathrm{kPa}$, producing lower initial water content (void ratio) values for the $40 \mathrm{kPa}$ load stage. Second, the salt grains in this specimen would have already been totally dissolved before the start of the $40 \mathrm{kPa}$ load stage, and considering its lower initial water content, the amount of strain produced under $40 \mathrm{kPa}$ load stage was lower compared with peat specimen $\mathrm{P} 2(\mathrm{u}) / 76 / 40 / 8$.

The addition of salt grains was also found to have an effect on the creep response. For instance, values of the coefficient of secondary compression $\left(C_{\alpha}=\Delta e / \Delta \log t\right)$ and secondary compression ratio $\left(C_{\mathrm{sec}}=C_{\alpha} /\left(1+e_{0}\right)\right)$ for salt-treated specimen $\mathrm{P} 2(\mathrm{cs}) / 76 / 20 / 1$ of 0.13 and 0.013 , respectively, were marginally greater than corresponding values for peat specimen $\mathrm{P} 2(\mathrm{u}) / 76 / 20 / 1$; where $e_{0}$ is the initial void ratio and $\Delta e$ the change in void ratio for a particular load stage and time period $t$. An apparent tertiary compression evident in the end portion of the strain curve for peat specimen $\mathrm{P} 2(\mathrm{u}) / 76 / 40 / 17$ was largely absent for salt-treated specimen P2(fs)/76/40/8 (Figure 4(a)). Tertiary compression is generally associated with strain ensuing from some decomposition of the peat solids occurring over the course of experimental laboratory testing (Mesri et al., 1997). It is postulated that the salt treatment may have changed the salinity of the peat specimen, possibly creating a less favourable environment for microbial decomposition to occur and therefore a more stable creep rate under loading.

From the oven-dried efflux, the water expelled from salt-treated P2 material under loading in the $76 \mathrm{~mm}$ diameter consolidation cell had a measured salt concentration of $92 \mathrm{~g} / 1$ pore water. The measured concentration of salt remaining at the end of consolidation within specimen $\mathrm{P} 2(\mathrm{cs}) / 76 / 40 / 17$ was $21 \mathrm{~g} / 1$ pore water. The initial salt concentration in salt-treated $\mathrm{P} 2$ material was $30 \mathrm{~g} / 1$ pore water. These values, confirmed by a mass balance calculation, indicate that more than one-third of the original salt additive had been removed from the treated peat by way of expelled pore water.

\section{Summary and conclusions}

Under similar conditions of one-dimensional loading, treatment of fibrous peat specimens by inclusion of a relatively small amount of salt grains $(30 \mathrm{~g}$ dry salt/1 pore water in the present study) was found to produce a faster rate and greater magnitude of primary consolidation settlement, and hence higher coefficient of permeability values compared with untreated peat (control) specimens. More than one-third of the salt additive was removed from the treated peat by way of expelled pore water. In addition, the rate and magnitude of creep settlement were reduced because greater settlement had occurred during the preceding primary consolidation stage, which was explained by the larger volume of micropore water expelled when compared with the control specimens. The active period of the salt treatment was the period over which the salt grains contained in the peat remained undissolved; that is, the effect on the above properties is marginal once the salt grains have fully dissolved. Considering the risk of groundwater pollution brought about by the dissolved salt, further research is required to find alternative, more environmentally friendly additives before trialling the proposed approach in situ. 


\section{Acknowledgements}

The authors acknowledge the assistance of Martin Carney and Eoin Dunne with the geotechnical laboratory testing and Patrick Veale with the peat sampling at Clara bog. The first author gratefully acknowledges an IRCSET Embark Postgraduate Research Scholarship (grant number RS/2011/271) from the Irish Research Council.

\section{REFERENCES}

Adams Jl (1965) The engineering behaviour of a Canadian muskeg. Proceedings of the 6th International Conference on Soil Mechanics and Foundation Engineering, Montreal, vol. 1 , pp. 3-7.

ASTM (2004) D 2980-04: Standard test method for volume mass, moisture-holding capacity, and porosity of saturated peat materials. ASTM International, West Conshohocken, PA, USA.

ASTM (2007) D4427-07: Standard classification of peat samples by laboratory testing. ASTM International, West Conshohocken, PA, USA.

Berry PL and Poskitt TJ (1972) The consolidation of peat. Géotechnique 22(1): 27-52.

BSI (1990) BS1377-6: 1990: Methods for test for soils for civil engineering purposes. Part 6: Consolidation and permeability tests in hydraulic cells and with pore pressure measurement. BSI, London, UK.

Chen Y, Banin A and Schnitzer M (1976) Use of the scanning electron microscope for structural studies on soils and soil components. Proceedings of Workshop on Techniques for Particulate Matter Studies in SEM. IIT Research Institute, Chicago, IL, USA, Part III, pp. 425-432.

de Josselin de Jong G (1968) Consolidation models consisting of an assembly of viscous elements or a cavity channel network. Géotechnique 18(2): 195-228.

Deboucha S, Hashim R and Alwi A (2008) Engineering properties of stabilized tropical peat soils. Electronic Journal of Geotechnical Engineering 13(E): 1-9.

den Haan EJ (1996) A compression model for non-brittle soft clays and peat. Géotechnique 46(1): 1-16.

den Haan EJ and Edil TB (1994) Secondary and tertiary compression of peat. Proceedings of Advances in Understanding and Modelling the Mechanical Behaviour of Peat. Balkema, Rotterdam, the Netherlands, pp. 49-60.

Dhowian AW and Edil TB (1980) Consolidation behaviour of peats. Geotechnical Testing Journal 3(3): 105-114.

Edil TB, Fox PJ and Lan LT (1991) End-of-primary consolidation of peat. Proceedings of 10th European Conference on Soil Mechanics and Foundation Engineering, Florence, Italy, vol. 1, pp. 65-68.

Farrell ER (2012) Organics/peat soils. In ICE Manual of Geotechnical Engineering (Burland J, Chapman T, Skinner $\mathrm{H}$ and Brown M (eds)). ICE Publishing, London, UK, vol. 1, pp. $463-479$.

Hebib S and Farrell ER (2003) Some experiences on the stabilization of Irish peats. Canadian Geotechnical Journal 40(1): 107-120.
Helling CS, Chesters G and Corey RB (1964) Contribution of organic matter and clay to soil cation-exchange capacity as affected by the $\mathrm{pH}$ of the saturating solution. Soil Science Society of America Proceedings 28(4): 517-520.

Hemond HF and Goldman JC (1985) On non-Darcian water flow in peat. Journal of Ecology 73(2): 579-584.

Hobbs NB (1986) Mire morphology and the properties and behaviour of some British and foreign peats. Quarterly Journal of Engineering Geology 19(1): 7-80.

Hughes P and Glendinning S (2004) Deep dry mix ground improvement of a soft peaty clay using blast furnace slag and red gypsum. Quarterly Journal of Engineering Geology and Hydrogeology 37(3): 205-216.

Kalantari B, Prasad A and Huat BBK (2011) Stabilising peat soil with cement and silica fume. Proceedings of the Institution of Civil Engineers - Geotechnical Engineering 164(1): 33-39.

Kazemian S, Huat B and Moayedi H (2012) Undrained shear characteristics of tropical peat reinforced with cement stabilized soil column. Geotechnical and Geological Engineering 30(4): 753-759.

Kelly ML (1993) Hydrology, Hydrochemistry and Vegetation of Two Raised Bogs. PhD thesis, University of Dublin, Trinity College, Dublin, Ireland.

Lake JR (1961) Pore-pressure and settlement measurements during small scale laboratory experiments to determine the effectiveness of sand drains in peat. Proceedings of Conference on Pore Pressure and Suction in Soils. Butterworths, London, UK, pp. 52-60.

Lake JR (1963) A full-scale experiment to determine the effectiveness of vertical sand drains in peat under a road embankment in Dunbartonshire, Scotland. Proceedings of European Conference on Soil Mechanics and Foundation Engineering, Wiesbaden, Germany, vol. 1, pp. 351-356.

Landva AO and Pheeney PE (1980) Peat fabric and structure. Canadian Geotechnical Journal 17(3): 416-435.

McNulty EG (1991) Sand drain induced subsidence of a peat. Proceedings of the 4th International Symposium on Land Subsidence, Colorado, USA, pp. 333-340.

Mesri G and Ajlouni MA (2007) Engineering properties of fibrous peats. Journal of Geotechnical and Geoenvironmental Engineering 133(7): 850-866.

Mesri G, Stark TD, Ajlouni MA and Chen CS (1997) Secondary compression of peat with or without surcharging. Journal of Geotechnical and Geoenvironmental Engineering 123(5): 411-421.

Ohira Y (1977) Methods of test and investigation. In Engineering Problems of Organic Soils in Japan. Research Committee on Organic Soils, Tokyo, special republication, pp. 19-33.

O'Kelly BC (2005a) Compressibility of some peats and organic soils. Proceedings of International Conference on Problematic Soils, Cyprus, vol. 3, pp. 1193-1202.

O'Kelly BC (2005b) Consolidation properties of a dewatered municipal sewage sludge. Canadian Geotechnical Journal 42(5): 1350-1358, http://dx.doi.org/10.1139/t05-054.

O'Kelly BC (2006) Compression and consolidation anisotropy of 
some soft soils. Geotechnical and Geological Engineering 24(6): 1715-1728, http://dx.doi.org/10.1007/s10706-005$5760-0$.

O'Kelly BC (2009) Development of a large consolidometer apparatus for testing peat and other highly organic soils. SUO - Mires and Peat 60(1-2): 23-36.

O'Kelly BC (2013) Characterisation and undrained strength of amorphous clay. Proceedings of the Institution of Civil Engineers - Geotechnical Engineering, in press, http:// dx.doi.org/10.1680/geng.11.00025.

O'Kelly BC and Zhang L (2013) Consolidated-drained triaxial compression testing of peat. ASTM Geotechnical Testing Journal 36(3): 310-321, http://dx.doi.org/10.1520/ GTJ20120053.

Ong HL and Bisque RE (1968) Coagulation of humic colloids by metal ions. Soil Science 106(3): 220-224.

Osorio JP (2012) Vacuum Consolidation Field Test on a PseudoFibrous Peat. $\mathrm{PhD}$ thesis, University of Dublin, Trinity College, Dublin, Ireland.

Osorio JP, Farrell ER, O'Kelly BC and Casey T (2008) Rampart roads in the peat lands of Ireland: genesis, development and current performance. In Proceedings of the 1st International Conference on Transportation Geotechnics, Nottingham, UK (Ellis E, Yu HS, Mcdowell G, Dawson AR and Thom N (eds)). CRC Press/Balkema, Leiden, Netherlands, vol. 1, pp. $227-$ 233.

Osorio JP, Farrell ER and O'Kelly BC (2010) Peat improvement under vacuum preloading: a novel approach for bog roads in Ireland. Proceedings of the Joint Symposium on Bridge and Infrastructure Research in Ireland and Concrete Research in Ireland 2010, Cork, Ireland, vol. 1, pp. 255-262.

Pichan SP and O'Kelly BC (2012) Effect of decomposition on the compressibility of fibrous peat. In ASCE GeoCongress 2012:
State of the Art and Practice in Geotechnical Engineering, Oakland, California, USA (Hryciw RD, AthanasopoulosZekkos A and Yesiller N (eds)). American Society of Civil Engineers, Reston, VA, pp. 4329-4338, http://dx.doi.org/ 10.1061/9780784412121.445(GSP 225).

Pichan SP and O'Kelly BC (2013) Stimulated decomposition in peat for engineering applications. Proceedings of the Institution of Civil Engineers - Ground Improvement 166(3): 168-176, http://dx.doi.org/10.1680/grim.12.00003.

Santagata M, Bobet A, Johnston CT and Hwang J (2008) Onedimensional compression behaviour of a soil with high organic matter content. Journal of Geotechnical and Geoenvironmental Engineering 134(1): 1-13.

Song S, Peng C, Gonzalez-Olivares MA, Lopez-Valdivieso A and Fort T (2005) Study on hydration layer near nanoscale silica dispersed in aqueous solution through viscosity measurement. Journal of Colloid and Interface Science 287(1): 114-120.

Stevenson FJ (1994) Humus Chemistry, Genesis, Composition, Reactions. Wiley, New York, USA.

Taylor DW (1942) Research on Consolidation of Clays. Massachusetts Institute of Technology (MIT), USA, publication from Department of Civil and Sanitary Engineering, Serial 82.

Wong LS, Hashim R and Ali FH (2008) Engineering behaviour of stabilized peat soil. European Journal of Scientific Research 21(4): 581-591.

Wong LS, Hashim R and Ali FH (2009) A review on hydraulic conductivity and compressibility of peat. Journal of Applied Sciences 9(18): 3207-3218.

Zhang L and O'Kelly BC (2013) The principle of effective stress and triaxial compression testing of peat. Proceedings of the Institution of Civil Engineers, Geotechnical Engineering, in press, http://dx.doi.org/10.1680/geng.12.00038.

\footnotetext{
WHAT DO YOU THINK?

To discuss this paper, please email up to 500 words to the editor at journals@ice.org.uk. Your contribution will be forwarded to the author(s) for a reply and, if considered appropriate by the editorial panel, will be published as a discussion in a future issue of the journal.

Proceedings journals rely entirely on contributions sent in by civil engineering professionals, academics and students. Papers should be 2000-5000 words long (briefing papers should be 1000-2000 words long), with adequate illustrations and references. You can submit your paper online via www.icevirtuallibrary.com/content/journals, where you will also find detailed author guidelines.
} 